\title{
Article
}

\section{Major Products Obtained from Plasma Torch Pyrolysis of Sunflower-Oil Cake}

Je-Lueng Shie, Ching-Yuan Chang, Wen-Kai Tu, Yu-Chieh Yang, Jui-Ke Liao, Chin-Ching Tzeng, Heng-Yi Li, Yuh-Jenq Yu, Ching-Hui Kuo, and Lieh-Chih Chang Energy Fuels, 2008, 22 (1), 75-82 • DOI: 10.1021/ef700301v • Publication Date (Web): 26 September 2007

Downloaded from http://pubs.acs.org on December 12, 2008

\section{More About This Article}

Additional resources and features associated with this article are available within the HTML version:

- Supporting Information

- Access to high resolution figures

- $\quad$ Links to articles and content related to this article

- Copyright permission to reproduce figures and/or text from this article

\section{View the Full Text HTML}




\title{
Major Products Obtained from Plasma Torch Pyrolysis of Sunflower-Oil Cake ${ }^{\dagger}$
}

\author{
Je-Lueng Shie,, Ching-Yuan Chang,,$\S$ Wen-Kai Tu, ${ }^{\S}$ Yu-Chieh Yang, ${ }^{\S}$ Jui-Ke Liao, ${ }^{\S}$ \\ Chin-Ching Tzeng," Heng-Yi Li," Yuh-Jenq Yu," Ching-Hui Kuo," and Lieh-Chih Chang" \\ Department of Environmental Engineering, National I-Lan University, I-Lan 260, Taiwan, Graduate \\ Institute of Environmental Engineering, National Taiwan University, Taipei 106, Taiwan, and Institute of \\ Nuclear Energy Research, Atomic Energy Council, Taoyuan County 325, Taiwan
}

Received May 28, 2007. Revised Manuscript Received August 11, 2007

\begin{abstract}
Bioenergy is now accepted as having a potential to provide a significant portion of the projected renewable energy provisions of the future. Therefore, biomass waste is one of the bioenergy sources and can be converted to syngas and liquid oil as a fuel or raw material to further produce chemical feedstocks. The carbon-containing residues can also be used as a carbon source. This study was proposed to study the feasibility and operation performance of plasma torch pyrolysis of biomass wastes, taking sunflower-oil cake as the target material. It was the biomass waste from the production process of biodiesel using sunflower seed. In the study, a plasma torch reactor was used for the pyrolysis of the sunflower-oil cake at different operating variables, such as temperature, input power, carrier gas, input mass, and reaction time. For the production of $\mathrm{CO}$ and $\mathrm{H}_{2}$ (syngas), the maximum accumulated mass fractions (or volume fractions) and the corresponding occurring temperatures are $93.17 \mathrm{wt} \%(51.17 \mathrm{vol} \%)$ of $\mathrm{CO}$ at $973 \mathrm{~K}$ and $8.21 \mathrm{wt} \%(56.13 \mathrm{vol} \%)$ of $\mathrm{H}_{2}$ at $1173 \mathrm{~K}$, respectively. The yield of $\mathrm{H}_{2}$ increases with the increase of the temperature. At $873 \mathrm{~K}, \mathrm{CO}$ and $\mathrm{H}_{2}$ have near equal volume fractions of 49.1 and $48.72 \mathrm{vol} \%$, respectively. At $973 \mathrm{~K}$, the reaction rate and syngas yield have the highest values and the yields of the pollutant have the lowest ones. Therefore, the optimum reaction condition should be controlled at $973 \mathrm{~K}$ or $14-22 \mathrm{~kW}$ of power. Further, the related literature was surveyed and reviewed. In summary, this study aims at the need to obtain useful information for converting the sunflower-oil cake to fuels or chemicals via the proposed plasma torch pyrolysis technique, which can provide appropriate use of bioenergy sources, such as biomass wastes, approaching the appeal to meet full recycling of biomass wastes and zero biomass wastes.
\end{abstract}

\section{Introduction}

The pyrolysis of biomass to produce syngas offers an alternative supply of energy other than fossil fuels. Because syngas contains essentially molecular hydrogen and carbon monoxide, it has the potential for use as a high-quality fuel. Moreover, after purification, it becomes an important source of hydrogen, which is anticipated to be used in future transport means employing fuel-cell technology. ${ }^{1}$ The diversity of thermal processes used for waste treatment ranges from the exothermic combustion process through gasification to pyrolysis. The combustion is characterized via the excess of oxygen, thereby emitting waste gases with high organic content. The pyrolysis is an endothermic process with an external power source using no or very little oxygen. In between, gasification is a process with much less oxygen involved. In comparison to the advantages of pyrolysis versus incineration, the production of syngas is much more economical and ecological because the syngas is a much more valuable commodity resulting from pyrolysis or gasification. Syngas is essentially a clean fuel with almost no

\footnotetext{
${ }^{\dagger}$ Presented at the International Conference on Bioenergy Outlook 2007, Singapore, April 26-27, 2007.

* To whom correspondence should be addressed. Telephone: +886-22363-8994. Fax: +886-2-2363-8994. E-mail: cychang3@ntu.edu.tw.

* National I-Lan University.

$\S$ National Taiwan University.

"Atomic Energy Council.

(1) Tendler, M.; Rutberg, P.; van Oost, G. Plasma Phys. Controlled Fusion 2005, 47, A219-A230.
}

ashes left and much less toxic compounds, such as dioxins and furans, produced from further treatment after use. Syngas may be also used for synthesizing many highly useful organic compounds. ${ }^{2-4}$ However, there are some problems that occur in conventional pyrolysis processes, such as low gas productivity and the generation of heavy tarry compounds. ${ }^{5-8}$ These problems can be overcome via the use of thermal plasma pyrolysis, which offers some unique advantages for biomass conversion, such as providing a high temperature and heating rate, in comparison to conventional pyrolysis. ${ }^{9-11}$ Thermal plasma also offers the possibility of the decomposition of biomass by pure pyrolysis in the absence of oxygen. The high energy density and temperature associated with thermal plasmas and the corre-

(2) Watanabe, T.; Shimbara, S. J. High Temp. Mater. Process 2003, 7, 455-474.

(3) Hlina, M.; Hrabovsky, M.; Kopecky, V.; Konrad, M.; Kavka, T.; Skoblja, S. Czech. J. Phys. 2006, 56, B1179-B1184.

(4) van Oost, G.; Hrabovsky, M.; Kopecky, V.; Konrad, M.; Hlina, M.; Chumak, A.; Beeckman, E.; Verstraeten, J. Vacuum 2006, 80, 1132-1137.

(5) Bridgwater, A. V. Chem. Eng. J. 2003, 91, 87-102.

(6) Chen, G.; Andries, K.; Luo, Z.; Spliethoff, H. Energy Convers. Manage. 2003, 44, 1875-1884.

(7) Mérida, W.; Maness, P. C.; Brown, R. C.; Levin, D. B. Int. J. Hydrogen Energy 2004, 29, 283-290.

(8) Yaman, S. Energy Convers. Manage. 2004, 45, 651-671.

(9) Fulcheri, L.; Schwob, Y. Int. J. Hydrogen Energy 1995, 20, 197202.

(10) Baumann, H.; Bittner, D.; Beiers, H. G.; Klein, J.; Juntgen, H. Fuel 1998, 67 (8), 1120-1123.

(11) Zhao, Z.; Huang, H.; Wu, C.; Li, H.; Chen, Y. Chem. Eng. Technol. 2001, 24 (5), 197-199. 
sponding fast reaction times provide a potential solution for the problems that occur in conventional pyrolysis processes. ${ }^{5-8}$ Plasma technology is very drastic because of the presence of highly reactive atomic and ionic species and the achievement of higher temperatures in comparison to other thermal methods. However, in fact, the extremely high temperatures (several thousands of degrees on the Celsius scale) occur only in the core of the plasma, while the temperature decreases substantially in the marginal zones. ${ }^{12}$ The electrical energy provides the energy need of the plasma torch, which then transfers its energy to the substances to be treated, thereby triggering dual simultaneous reaction processes in the plasma-chemical reactor. The organic compounds are thermally decomposed into simple compounds or their constituent elements. The conversion of $\mathrm{C}$ into syngas is more complete via the plasma torch reactor than the incinerator. The inorganic materials are melted and converted into a dense, inert, and nonleachable vitrified slag that does not require controlled disposal. The plasma torch process also acts as a means for energy storing. The electrical energy is transformed to plasma energy and then stored in the produced syngas. The main advantages are a better control of the composition of the produced gas, higher heat capacity of the gas, reduction of unwanted contaminants, such as tar and $\mathrm{CO}_{2}$, and higher hydrocarbons. ${ }^{4}$ The criteria of optimization of the treatment of feedstocks are (1) the maximum energy content of the syngas for electricity or heat production (thermal conversion) and (2) the production or recovery of a valuable byproduct from the syngas, such as methanol or hydrogen, for fuel cells (chemical conversion). ${ }^{4}$ Nevertheless, until now, thermal plasmas have usually only been applied for the destruction of noxious materials (such as polypropylene, ${ }^{13}$ electroplating sludges, ${ }^{14}$ polychlorinated biphenyls (PCBs), ${ }^{15}$ 1,2-dichloroethane (DCE), ${ }^{16}$ halogenated hydrocarbons, ${ }^{2}$ and benzene ${ }^{17}$ ), because of the high electrical power consumption. Thermal plasma pyrolysis of biomass for energy and chemical production has seldom been studied even in laboratory investigations for technical and economic reasons. ${ }^{11,18}$

Recently, a new research and development program on the technology about applications of a pilot-scale plasma torch for biomass energy use has been started and conducted at the Institute of Nuclear Energy Research, Atomic Energy Council (INER-AEC) of Taiwan, together with the academic partners of the National Taiwan University (NTU) and National I-Lan University (NIU). This study presents the results of the program. The treatment of biomass using thermal plasma torch as the heat source was investigated. Pyrolysis experiments were performed using carrier gas of $\mathrm{N}_{2}$ injected at temperature ranges from 800 to $1300 \mathrm{~K}$. The biomass tested in this study was sunflower-oil cake. It is the residue from the pressed sunflower seed for the edible sunflower oil or biodiesel. The promotion of the production and usage of biodiesel in Taiwan is at its beginning. Under the plan of the Nuclear-Free Homeland of Taiwan in 2005, over 700 garbage trucks in 13 counties of Taiwan were on track. It was the first extensive test on the use

(12) Moustakas, K.; Fatta, D.; Malamis, S.; Haralambous, K.; Loizidou, M. J. Hazard. Mater. 2005, B123, 120-126.

(13) Guddeti, R. R.; Knight, R.; Grossmann, E. D. Ind. Eng. Chem. Res. 2000, 39, 1171-1176.

(14) Ramachandran, K.; Kikukawa, N. IEEE Trans. Plasma Sci. 2002, $30,310-317$.

(15) Kim, S. W.; Park, H. S.; Kim, H. J. Vacuum 2003, 70, 59-66.

(16) Li, C. T.; Yang, R. B.; Shih, M. L.; Chen, C. Y.; Hsieh, L. T. J. Chem. Technol. Biotechnol. 2003, 78, 817-823.

(17) Shih, S. I.; Lin, T. C.; Shih, M. L. J. Hazard. Mater. 2004, 116, 239-248.

(18) Tang, L.; Huang, H. Energy Fuels 2005, 19, 1174-1178. of biodiesel for diesel vehicles in Taiwan. ${ }^{19}$ Thus, the main objective of the present paper is to assess the plasma torch pyrolysis of waste biomass of sunflower-oil cake and examine the effects of operation parameters on the performance. The previous studies in the literature as noted in the above sections provided some useful information of thermal treatment and plasma pyrolysis of biomass but gave no data about products from the pyrolysis of sunflower-oil cake using the plasma torch. It is thus the aim of the present work to deal with the pyrolysis of sunflower-oil cake with the viewpoint of providing product distribution. The pyrolysis was performed using a pilot-scale plasma torch system in a nitrogen atmosphere. The residual materials and noncondensable gases were collected and analyzed, employing an elemental analyzer, inductively coupled plasma/atomic emission spectrometer (ICP/AES), gas analytical instruments, and gas chromatography analyzers with a thermal conductivity detector (GC-TCD) and flame ionization detector (GC-FID).

\section{Experimental Section}

Apparatus and Procedures. Materials. The sunflower-oil cake used in this study was sampled from the de-oil sunflower seed after pressing. The sunflower seed was cropped by farmers supported by the Council of Agriculture of Taiwan (TCOA). The sample of sunflower-oil cake was dried in a recycle ventilation drier for $24 \mathrm{~h}$ at $378 \mathrm{~K}$ before use.

Pilot-Scale Plasma Torch Process. The plasma torch pyrolysis technology has been applied by the INER-AEC of Taiwan and used for bioenergy production by the NTU and NIU of Taiwan. Tests have been performed to set the relevant specifications for the development of a relevant pilot unit, aiming at exploring its potential in biomass treatment and use. The pilot-scale apparatus used and the experimental procedures for the plasma torch pyrolysis of sunflower-oil cake are shown in Figure 1. A $60 \mathrm{~kW}$ plasma torch was used for the pyrolysis purpose. For batch feeding, a sample of known pelletized mass $(50 \mathrm{~g})$ was placed on the sample input apparatus for feeding the sample material. For continuous feeding, samples were sequentially fed into the reactor. The developed plasma torch pyrolysis unit consists of the following parts:

1. Air Compressor. The primary purpose of the air compressor is to compress air into the $\mathrm{N}_{2}$-separation device for the production of the carrier gas of $\mathrm{N}_{2}$.

2. $N_{2}$-Separation Device. The air gas with a proper flow rate was first introduced into the $\mathrm{N}_{2}$-separation device to separate $\mathrm{N}_{2}$ and $\mathrm{O}_{2}$. Then, the flow rate of the carrier gas of $\mathrm{N}_{2}\left(Q_{\mathrm{N}}\right)$ was adjusted to the desired value, say $100 \mathrm{~L} \mathrm{~min}^{-1}$ at $101.3 \mathrm{kPa}(1$ atm) and $293 \mathrm{~K}$, and controlled by a rotameter.

3. Power-Supply Chopper. For the power supply, the powersupply control unit (chopper) (Taiwan Plasma Corp.) of the plasma torch reactor was set at a specific power $\left(P_{\mathrm{L}}\right)$ in the range of 5-45 $\mathrm{kW}$ for the temperatures $(T)$ from 400 to $1700 \mathrm{~K}$, respectively. $P_{\mathrm{L}}$ for the plasma torch used has a maximum power output of $60 \mathrm{~kW}$. After the ignition by tricker, the $T$ can also be adjusted via $Q_{\mathrm{N}}$ or the current from the chopper $\left(I_{\mathrm{C}}\right)$.

4. Argon Cylinder. For the ignition of the plasma torch, the flow rate of argon $\left(Q_{\mathrm{Ar}}\right)$ of $10 \mathrm{~L} \mathrm{~min}^{-1}$ is needed in the initiating process.

5. Sample Input Apparatus. The primary sample feeding system consists of a closed cylinder hopper with upper and lower covers. The hopper has a maximum size of $42 \mathrm{~mm}$ in diameter and $55 \mathrm{~mm}$ in length. The sample feeder has a maximum capacity of about 50 $\mathrm{kg} \mathrm{h}^{-1}$ of sample, and the feeding capacity varies depending upon the bulk density of the feed sample. The dried sample was placed in the hopper that can be enclosed by upper and lower covers. The covers were alternatively opened for feeding. For an accurate

(19) Chuang, G. L. A study on the influences of biodiesel in use for diesel vehicle on engine performance and characteristics of exhaust in Taiwan. Master's Thesis, Graduate Institute of Environmental Engineering, National Taiwan University, Taiwan, 2007. 


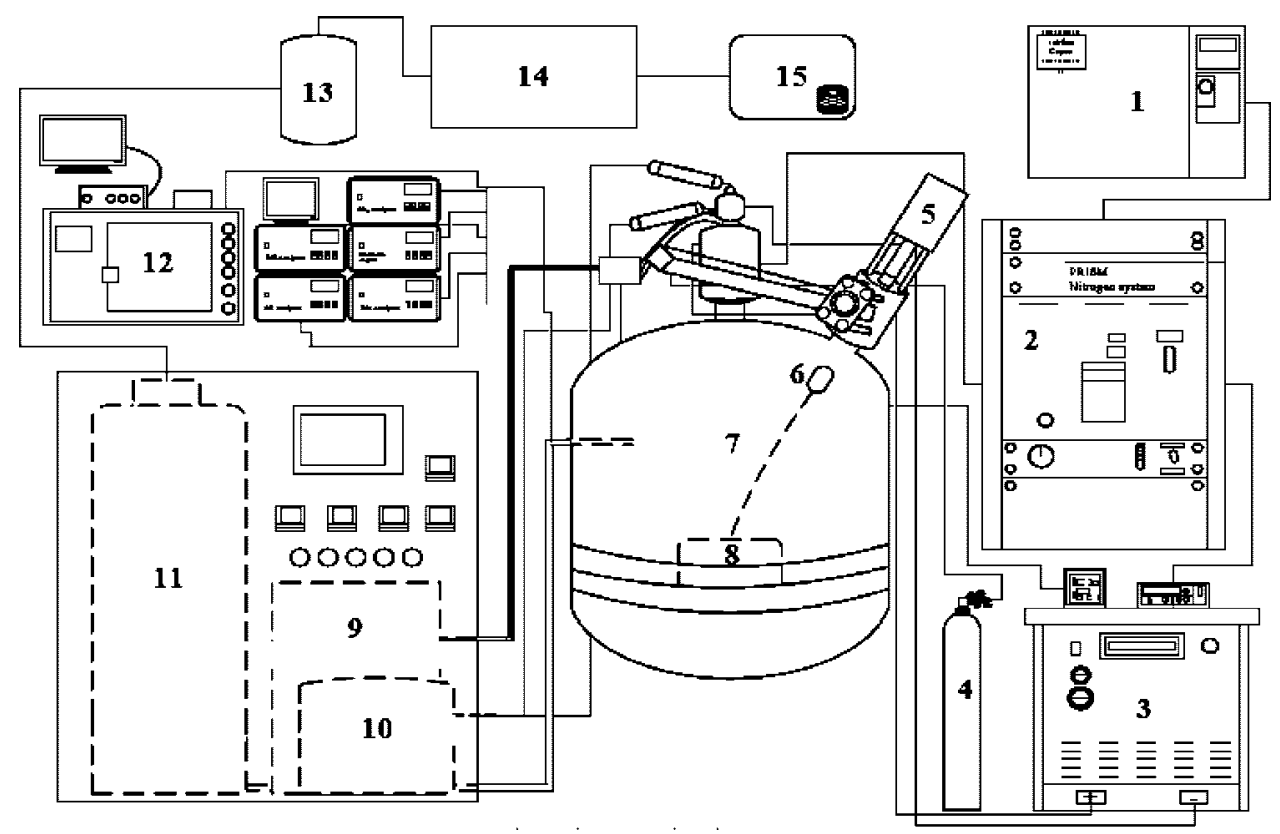

Figure 1. Schematic diagram of the apparatus for the $60 \mathrm{~kW}$ plasma torch. (1) Air compressor, (2) $\mathrm{N}_{2}$-separation device, (3) power-supply chopper, (4) argon cylinder, (5) sample input apparatus, (6) sample, (7) plasma torch and reactor, (8) water condenser bath, (9) quench system, (10) gas detectors and analytical instruments, (11) storage tank, and (12) direct burner.

comparison of the effects from temperatures, the feeding type used in this study was batch-feeding with a $50 \mathrm{~g}$ sample for one run at a set temperature.

6. Sample. The sunflower-oil cake sample was dried in a recycle ventilation drier for $24 \mathrm{~h}$ at $378 \mathrm{~K}$ before use. For easy delivering and feeding, the sunflower-oil cake was pelletized to a cylinder, with the pellet size of $35 \mathrm{~mm}$ in diameter and $50 \mathrm{~mm}$ in length.

7. Plasma Torch and Reactor. The plasma torch converts electrical to thermal energy and is the key for the treatment of the sample in the reactor. The applied high voltage on the electrodes results in electric discharges, which in turn generate the current flowing from the anode $(+)$ to the cathode $(-)$ through the gas passing by. The ignition gas, such as Ar, is initially introduced and ignited because the voltage is high enough, forming the plasma torch. After the ignition of the plasma torch, the carrier gas, such as $\mathrm{N}_{2}$, is then introduced. A certain percentage of its molecules is partially or totally ionized, using the dissipation of resistive energy, which also makes the gas sufficiently hot. The ionized gas is thus in the plasma state. The reactor is comprised of a crucible, with approximately $2 \mathrm{~L}$ in capacity. Two shells were used for refractory insulation in the reactor, with outer and inner layers of 4 and $8 \mathrm{~cm}$ in thickness, which can tolerate the temperatures as high as 1673 and $2073 \mathrm{~K}$, respectively. The plasma was ejected from the torch into the reactor and contacted with the sample directly. A thermocouple was inserted into the reactor for measuring the temperature of the plasma gas. The power supply was controlled via the feedback information from temperature readings.

8. Water Condenser Bath. The system was operated under atmospheric pressure. The effluent gas flowed through a clad duct for safety reasons and into a water-cooling bath and then vented to a quench system. Because the synthesis gas may contain acid gases (such as $\mathrm{HCl}$ or $\mathrm{SO}_{2}$ ), the water-cooling bath can remove watersoluble components of the off-gas, including hydrochloric acid, most oxides of sulfur, and suspended particles, prior to discharge into the quench system.

9. Quench System. It is located at the outlet of the water-cooling bath. Its role is to further quickly cool the gases to approximate $348 \mathrm{~K}$ to minimize any production of dioxins, furans, or other organic compounds. The shock cooling avoids the formation of the aforementioned compounds from elementary molecules in the synthesis gas because of the de novo synthesis back reactions. ${ }^{29}$ These reactions are known to occur in waste fuel gas of boilers, where a slow cooling is applied in the range from 673 to $523 \mathrm{~K}$ for the flue gases with chlorine compounds, noncombusted organic molecules, and catalysts, such as dust. The synthesis back reactions will result in dioxin formation. The quench vessel uses two atomizing nozzles to quench the gas. Regulating the amount of the quenching water can control the gas temperature exiting the vessel.

10. Gas Detectors and Analytical Instruments. To measure the gas products, a gas chromatography and four analytical instruments for specific gases were connected to the outlet clad duct of the reactor for online detection. The gas products were parallel-inhaled to the detectors. For the analysis of $\mathrm{H}_{2}$, a China Chromatography 8900 GC-TCD with a Supelco packing column (60/80 carbonxen1000, $15 \mathrm{ft}$ long, $2.1 \mathrm{~mm}$ i.d.) was used. The operation conditions were set as follows: injector temperature, $453 \mathrm{~K}$; detector temperature, $513 \mathrm{~K}$; column temperature (following the sampling injection) being held at $513 \mathrm{~K}$ for $10 \mathrm{~min}$; helium carrier gas flow rate, 30 $\mathrm{mL} \mathrm{min}^{-1}$ for A and B columns; and sample volume, $2 \mathrm{~mL}$. For the analyses of $\mathrm{CO}, \mathrm{CO}_{2}, \mathrm{NO}_{x}, \mathrm{SO}_{2}$, and $\mathrm{HCl}$, four gas analyzers of Thermo Environmental Instruments, Inc. were used. The operation conditions of flow rates, internal temperatures, and chamber temperatures were (1) $0.183 \mathrm{~L} \mathrm{~min}^{-1}, 305$ and $321 \mathrm{~K}$ of $\mathrm{CO},(2) 0.928 \mathrm{~L} \mathrm{~min}^{-1}, 301$ and $319 \mathrm{~K}$ of $\mathrm{CO}_{2}$, (3) $0.684 \mathrm{~L} \mathrm{~min}^{-1}$,

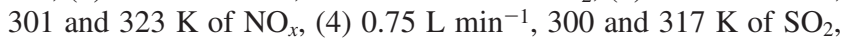
and (5) $0.75 \mathrm{~L} \mathrm{~min}^{-1}, 302$ and $317 \mathrm{~K}$ of $\mathrm{HCl}$, respectively. Meanwhile, the data acquisition unit, with a sampling interval of $60 \mathrm{~s}$, proceeded throughout the entire run. Several duplicate experimental runs were performed to get the correct values.

11. Storage Tank. For the storage of syngas, a storage tank was set in this process.

12. Direct Burner. The direct burner is designed to combust $\mathrm{H}_{2}$ and $\mathrm{CO}$ in the synthesis gas to be emitted. To combust $\mathrm{CO}$ and $\mathrm{H}_{2}$ into $\mathrm{CO}_{2}$ and $\mathrm{H}_{2} \mathrm{O}$, air and fuel were added into the direct burner, which was kept to certain high temperature. The suitable high temperature was required to fully combust $\mathrm{CO}$ and $\mathrm{H}_{2}$ in a region where no hazardous byproducts were created and then vented to the atmosphere.

Elemental Analyses. The elemental analyses for the sunfloweroil cake and sunflower seed were made on a Perkin-Elmer, Norwalk, CT2400 elemental analyzer with $0.3 \mathrm{wt} \%$ accuracy. The elements of $\mathrm{C}, \mathrm{H}$, and $\mathrm{N}$ were analyzed via Heraeus CHN-O-RAPID, and $\mathrm{S}$ and $\mathrm{Cl}$ were analyzed via a Tacussel Coulomax 78 automatic coulometric titrator.

Metal Analyses. The heavy metals in the sunflower seed were measured on the ICP/AES (Jarrel-Ash, ICAP 9000). The mass of the sample used for the digestion experiment was $0.5 \mathrm{~g}$. For the purposes of analysis, the samples were pretreated by mixing with 
Table 1. Some Properties of Sunflower Seed and Sunflower-Oil Cake Used in This Study

\begin{tabular}{|c|c|c|}
\hline \multirow[b]{2}{*}{ item } & \multicolumn{2}{|c|}{ property } \\
\hline & sunflower seed & sunflower-oil cake \\
\hline \multicolumn{3}{|c|}{ Proximate Analysis (wt \%) } \\
\hline moisture & $0.55(0.039)^{a}$ & $7.19(0.45)^{a}$ \\
\hline combustible & $98.53(0.04)$ & $82.11(2.75)$ \\
\hline ash & $0.93(0.006)$ & 10.74 (3.13) \\
\hline $\begin{array}{l}\text { oil content of squeezing } \\
\left(w t w t^{-1}\right)\end{array}$ & 50 & $14.56(1.83)$ \\
\hline heating value $\left(\mathrm{kcal} \mathrm{kg}^{-1}\right)$ & & \\
\hline $\begin{array}{l}\text { heating value on dry basis } \\
\qquad(\mathrm{k} \mathrm{cal} \mathrm{kg}), H_{\mathrm{d}}\end{array}$ & 6053 & 5211 \\
\hline $\begin{array}{l}\text { high heating value on wet basis } \\
\qquad\left(\mathrm{kcal} \mathrm{kg}^{-1}\right), H_{\mathrm{h}}{ }^{b}\end{array}$ & 6020 & 4836 \\
\hline $\begin{array}{l}\text { low heating value on wet basis } \\
\quad\left(\mathrm{kcal} \mathrm{kg}^{-1}\right), H_{\mathrm{L}}\end{array}$ & 5579 & 4375 \\
\hline \multicolumn{3}{|c|}{ Ultimate Analysis (Dry Basis, wt \%) } \\
\hline $\mathrm{C}$ & $54.18(0.25)$ & $47.61(0.14)$ \\
\hline $\mathrm{H}$ & 8.14 (1.02) & $8.33(0.06)$ \\
\hline $\mathrm{N}$ & $3.42(0.12)$ & $5.04(0.01)$ \\
\hline $\mathrm{O}$ & 33.99 (balance) & 38.79 (balance) \\
\hline $\mathrm{S}$ & $0.23(0.11)$ & $0.19(0.001)$ \\
\hline $\mathrm{Cl}$ & 0.037 & 0.037 \\
\hline
\end{tabular}

Table 2. Elemental Analyses of Metals of Sunflower Seed and Sunflower-Oil Cake (Dry Basis) ${ }^{a}$ Used in This Study

\begin{tabular}{|c|c|c|c|c|c|c|c|c|c|c|}
\hline elemental & K & $\mathrm{P}$ & $\mathrm{Mg}$ & $\mathrm{Ca}$ & $\mathrm{Fe}$ & $\mathrm{Si}$ & $\mathrm{Al}$ & $\mathrm{Na}$ & $\mathrm{Zn}$ & $\mathrm{Cu}$ \\
\hline $\begin{array}{l}\text { sunflower } \\
\text { seed }\end{array}$ & & & & & 138 & & 82 & & 58 & \\
\hline $\begin{array}{c}\text { sunflower- } \\
\text { oil cake }\end{array}$ & 14400 & 9150 & 5260 & 3290 & $0 \quad 430$ & 250 & 130 & 130 & 60.5 & 27.8 \\
\hline elemental & $\mathrm{Mn}$ & $\mathrm{Ni}$ & $\mathrm{Sr}$ & $\mathrm{Ba}$ & $\mathrm{Cr}$ & $\mathrm{Au}$ & $\mathrm{Cd}$ & $\mathrm{Pb}$ & $\mathrm{Hg}$ & $\mathrm{Ag}$ \\
\hline $\begin{array}{l}\text { sunflower } \\
\text { seed }\end{array}$ & & & & & 3.77 & $\mathrm{ND}^{b}$ & ND & ND & $\mathrm{ND}$ & $\overline{N D}$ \\
\hline $\begin{array}{l}\text { sunflower- } \\
\text { oil cake }\end{array}$ & 20 & 12.9 & 11.9 & 9.9 & ND & ND & ND & ND & ND & ND \\
\hline
\end{tabular}

$2 \mathrm{~mL}$ of concentrated $\mathrm{HNO}_{3}, 0.5 \mathrm{~mL}$ of $\mathrm{HClO}_{4}$, and $1 \mathrm{~mL}$ of $\mathrm{HF}$ and then digested at $443 \mathrm{~K}$ for $6 \mathrm{~h}$. The heating values of sunfloweroil cake and sunflower seed were measured by the adiabatic bomb calorimeter (O.S.K., 150 vacuum flask oxygen bomb calorimeter).

Chemicals. The gas standards used for analyses were $99.9999 \%$ $\mathrm{N}_{2}$ and $99.9 \% \mathrm{CO}_{2}, \mathrm{CO}, \mathrm{H}_{2}, \mathrm{HCl}$, and $\mathrm{SO}_{2}$. Quantitative analysis of gaseous products was based on the calculation using the linear calibration response equations of standards. The equation was generated for each of the gas standards using a minimum of five different concentrations with three replicates at each concentration. All correlation coefficients $\left(r^{2}\right)$ of linear calibration response curves were greater than 0.997 .

\section{Results and Discussion}

Characteristics of Sunflower-Oil Cake and Sunflower Seed. The tested biomass in this study was sunflower-oil cake. Sunflower-oil cake is the residue from the pressed sunflower seed for producing the edible sunflower oil or biodiesel. The results of proximate analysis, oil content of squeezing, heating value, and elemental analyses of sunflower seed and sunfloweroil cake are listed in Table 1 . The elemental analysis of the metal of sunflower seed is presented in Table 2. The contents of $\mathrm{C}$ and $\mathrm{O}$ of the sunflower-oil cake and sunflower seed are 47.61 and 54.18 wt \% for $\mathrm{C}$ and 38.79 and 33.99 wt \% for $\mathrm{O}$, respectively. It is obvious that the sulfur, chloride, nitrogen, and metal content are rare and can be neglected in the use of
Table 3. Operating Parameters for the Pyrolysis of Sunflower-Oil Cake Using the Plasma Torch at Various Temperatures

\begin{tabular}{ccccc}
\hline $\begin{array}{c}\text { target temperature } \\
\pm 20(\mathrm{~K})\end{array}$ & $\begin{array}{c}\text { initial mass } \\
(\mathrm{g})\end{array}$ & $\begin{array}{c}\text { power } \\
(\mathrm{kW})\end{array}$ & $\begin{array}{c}\text { total reaction } \\
\text { time }(\mathrm{min})\end{array}$ & $\begin{array}{c}t_{90} / m_{\mathrm{s}} \\
\left(\mathrm{min}^{-1}\right)\end{array}$ \\
\hline 873 & 50.33 & $13.86-20.6$ & 53 & 0.86 \\
& $(1.89)^{a}$ & & & $(0.07)$ \\
973 & 47.33 & $14.00-22.00$ & 57 & 0.62 \\
& $(0.94)$ & & & $(0.05)$ \\
1073 & 49 & $18.68-23.82$ & 78 & 0.95 \\
& $(0.00)$ & & & $0.06)$ \\
1173 & 49 & $17.76-24.26$ & 81 & 1.03 \\
& $(0.00)$ & & & $(0.2)$
\end{tabular}

${ }^{a}$ Numbers in parentheses are standard deviations $\left(\sigma_{n-1}\right)$.

sunflower-oil cake. ${ }^{20}$ Most of the biomass has about the same properties, and this is the main advantage of using biomass for energy and resource production from pyrolysis. ${ }^{21}$ Also, the reduced emissions of $\mathrm{CO}_{2}$ and $\mathrm{SO}_{2}$ as a result of the use of biomass for energy generation are further important for preventing the greenhouse effect and acid rain. ${ }^{22}$ Table 3 presents the operating parameters for the pyrolysis of sunflower-oil cake using the plasma torch at various temperatures. Temperatures were operated from 873 to $1173 \mathrm{~K}$. The input power increases with the increase of the reaction temperature and varies from 13.86 to $24.26 \mathrm{~kW}$. In fact, the temperature initiated in thermal plasma (usually $3000-10000 \mathrm{~K}$ ) is much too high for biomass pyrolysis; a great portion of the heat from the thermal plasma is released to the surroundings by means of radiation and conduction. ${ }^{18}$ Therefore, temperatures operated from 873 to 1173 $\mathrm{K}$ can avoid the useless heat released.

Properties of Instantaneous Gaseous Products. Carbon Monoxide and Hydrogen (Syngas). Gaseous samples were collected via the instantaneous sampling method and detected online using a gas chromatography and four analytical instruments of gases. The gas products were parallel-inhaled to the detectors from the outlet clad duct from the reactor. The instantaneous concentrations of $\mathrm{CO}[\mathrm{CO}]$ and $\mathrm{H}_{2}\left[\mathrm{H}_{2}\right]$ in gaseous products at various temperatures $(T)$ and reaction times $\left(t_{\mathrm{rsf}}\right.$, reaction time of the solid sample in the furnace after loading) are shown in Figures 2 and 3, respectively. From Figure 2, the maximum instantaneous concentrations and the corresponding $t_{\text {rsf }}$ of CO occur at (1) $60661 \mathrm{ppmv}$ and 2 min for $873 \mathrm{~K}$, (2) 89350 ppmv and $3 \mathrm{~min}$ for $973 \mathrm{~K}$, (3) $84896 \mathrm{ppmv}$ and $1 \mathrm{~min}$ for $1073 \mathrm{~K}$, and (4) $72756 \mathrm{ppmv}$ and $2 \mathrm{~min}$ for $1173 \mathrm{~K}$, respectively, with a $1 \mathrm{~min}$ sampling interval. Figure 3 shows that the maximum instantaneous $\left[\mathrm{H}_{2}\right]$ occurs at 5 min with $\left[\mathrm{H}_{2}\right]$ of 35800 ppmv for $873 \mathrm{~K}, 44850$ ppmv for $973 \mathrm{~K}, 43400$ ppmv for $1073 \mathrm{~K}$, and 35300 ppmv for $1173 \mathrm{~K}$, respectively, with a 5 min sampling interval. The productions of $\mathrm{CO}$ and $\mathrm{H}_{2}$ are the major components in the gas products, with the temperatures yielding the maximum concentrations at 973 and

(20) Calaminus, B.; Stahlberg, B. Waste Manag. 1998, 18, 547-556.

(21) Sharma, R. K.; Bakhshi, N. N. Can. J. Chem. Eng. 1991, 69, 10711081 .

(22) Liang, X. H.; Kozinski, J. A. Fuel 2000, 79, 1477-1486.

(23) Demirbas, A. Energy Convers. Manage. 2002, 43, 897-909.

(24) Zanzi, R.; Sjöström, K.; Björnbom, E. Biomass Bioenergy 2002, 23, 357-366.

(25) Lédé, J. J. Anal. Appl. Pyrolysis 2003, 70, 601-618.

(26) Tomasi, C.; Baratieri, M.; Bosio, B.; Arato, E.; Baggio, P. J. Power Sources 2006, 157, 765-774.

(27) Tang, L.; Huang, H.; Zhao, Z. L.; Wu, C. Z.; Chen, Y. Ind. Eng. Chem. Res. 2003, 42, 1145-1150.

(28) Rutberg, P. G.; Bratsev, A. N.; Ufimtsev, A. A. J. High Temp. Mater. Process 2004, 8, 433-446.

(29) Huang S. H. A study on the production processes and costs of biodiesel. Master's Thesis, Graduate Institute of Environmental Engineering, National Taiwan University, Taiwan, 2007. 


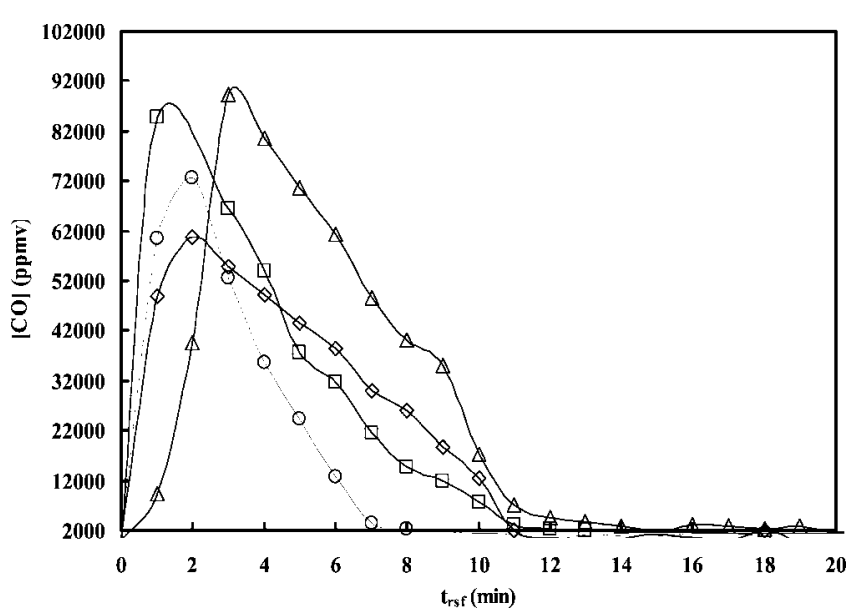

Figure 2. Instantaneous concentrations of $\mathrm{CO}$ in the gaseous product [CO] from the pyrolysis of sunflower-oil cake using the plasma torch. $(\diamond) 873 \mathrm{~K},(\triangle) 973 \mathrm{~K},(\square) 1073 \mathrm{~K}$, and $(\bigcirc) 1173 \mathrm{~K} . t_{\mathrm{rsf}}=$ reaction time of the solid sample in the furnace after loading.

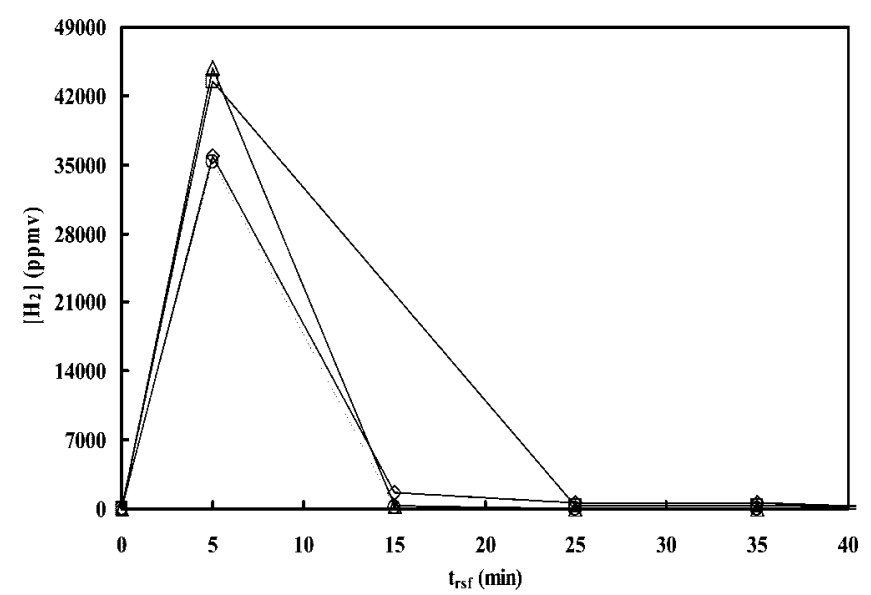

Figure 3. Instantaneous concentrations of $\mathrm{H}_{2}$ in the gaseous product $\left[\mathrm{H}_{2}\right]$ from the pyrolysis of sunflower-oil cake using the plasma torch. $(\diamond) 873 \mathrm{~K},(\triangle) 973 \mathrm{~K},(\square) 1073 \mathrm{~K}$, and $(\bigcirc) 1173 \mathrm{~K} . t_{\text {rsf }}=$ as specified in Figure 2.

$1173 \mathrm{~K}$, respectively. The conversion of $\mathrm{C}$ to $\mathrm{CO}$ is more vigorous than the formation of $\mathrm{H}_{2}$ as indicated in Figures 2 and 3 , with [CO] higher than $\left[\mathrm{H}_{2}\right]$. The times for the occurrence of maximum instantaneous concentrations of $\mathrm{H}_{2}$ are all $5 \mathrm{~min}$ longer than those of CO. However, in comparison to the conventional thermal pyrolysis, the reaction time of $5 \mathrm{~min}$ is considerably shorter. Thus, the elevated heating rate of the plasma torch allows the reaction to reach the condition with the maximum product concentration quickly. From the variation of the $\mathrm{CO}$ concentration with time as shown in Figure 2, the reaction time needed is only $15 \mathrm{~min}$ for the completion of the plasma torch pyrolysis of sunflower-oil cake in this study. Therefore, the plasma torch can be characterized with its elevated energy density that allows for the treatment of solid waste, such as sunflower-oil cake, to be faster than the conventional thermal methods.

Pollutants. Figure 4 shows that the maximum instantaneous concentrations (excluding the background concentration of 3340 ppmv) and the corresponding reaction times of $\mathrm{NO}_{x}$ that occur at $1286 \mathrm{ppmv}$ and $3 \mathrm{~min}$ for $873 \mathrm{~K}, 1.58 \mathrm{ppmv}$ and $11 \mathrm{~min}$ for $973 \mathrm{~K}, 3266 \mathrm{ppmv}$ and $1 \mathrm{~min}$ for $1073 \mathrm{~K}$, and 2604 ppmv and 4 min for $1173 \mathrm{~K}$, respectively, with a $1 \mathrm{~min}$ sampling interval. It is obvious that the formation of $\mathrm{NO}_{x}$ at $973 \mathrm{~K}$ can be neglected. From Figure 5, the maximum instantaneous concentrations and the corresponding reaction times of $\mathrm{CO}_{2}$ appear at

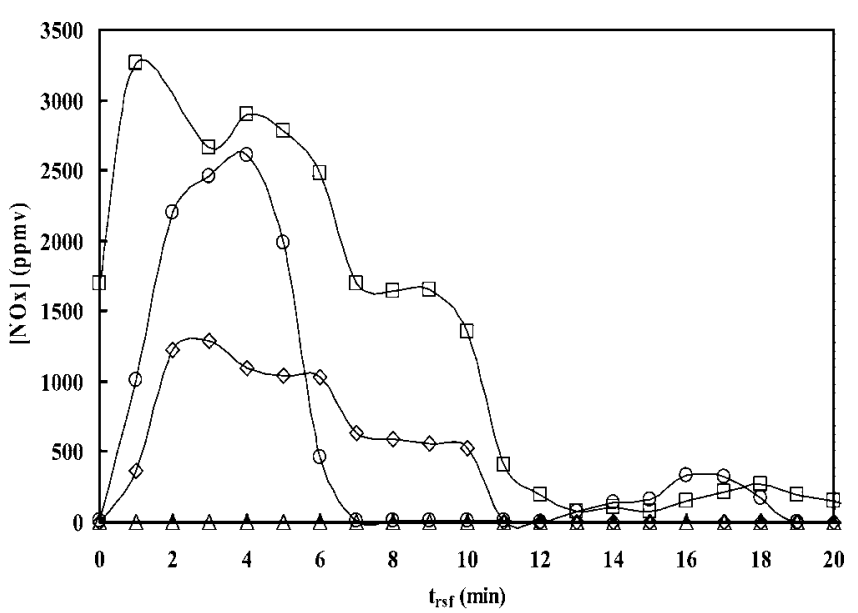

Figure 4. Instantaneous concentrations of $\mathrm{NO}_{x}$ in the gaseous product $\left[\mathrm{NO}_{x}\right]$ for the pyrolysis of sunflower-oil cake using the plasma torch. $(\diamond) 873 \mathrm{~K},(\triangle) 973 \mathrm{~K},(\square) 1073 \mathrm{~K}$, and $(\bigcirc) 1173 \mathrm{~K} . t_{\text {rsf }}=$ as specified in Figure 2.

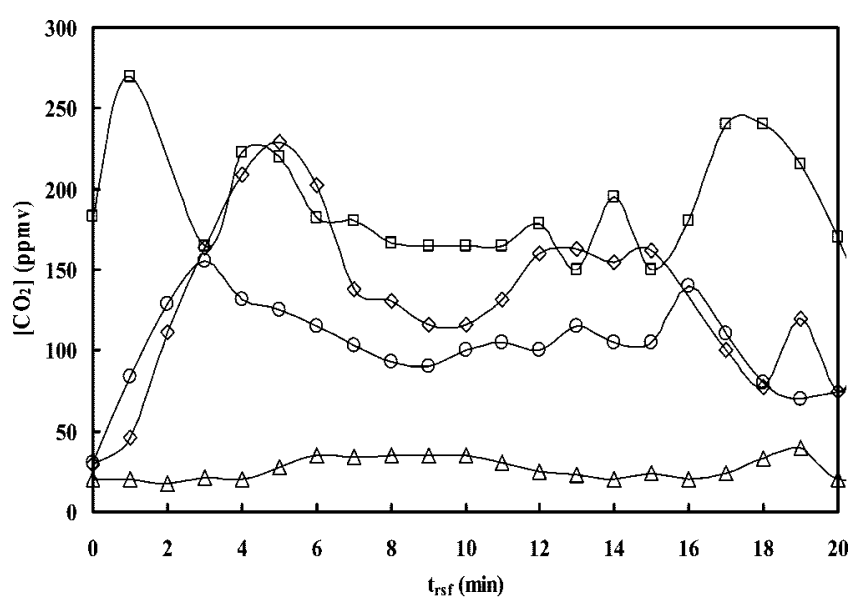

Figure 5. Instantaneous concentrations of $\mathrm{CO}_{2}$ in the gaseous product $\left[\mathrm{CO}_{2}\right]$ for the pyrolysis of sunflower-oil cake using the plasma torch. $(\diamond) 873 \mathrm{~K},(\triangle) 973 \mathrm{~K},(\square) 1073 \mathrm{~K}$, and $(\bigcirc) 1173 \mathrm{~K} . t_{\text {rsf }}=$ as specified in Figure 2.

$229 \mathrm{ppmv}$ and $5 \mathrm{~min}$ for $873 \mathrm{~K}, 40 \mathrm{ppmv}$ and $19 \mathrm{~min}$ for 973 $\mathrm{K}, 270 \mathrm{ppmv}$ and $1 \mathrm{~min}$ for $1073 \mathrm{~K}$, and $156 \mathrm{ppmv}$ and $3 \mathrm{~min}$ for $1173 \mathrm{~K}$, respectively, with a $1 \mathrm{~min}$ sampling interval. For the other pollutants (detailed results are not shown here), the maximum instantaneous concentrations and the corresponding reaction times at various temperatures occur at (1) $10 \mathrm{ppmv}$ and $8 \mathrm{~min}$ for $\mathrm{SO}_{2}$ and $11.42 \mathrm{ppmv}$ and $3 \mathrm{~min}$ for $\mathrm{HCl}$ at 873 $\mathrm{K}$, (2) $8.89 \mathrm{ppmv}$ and $9 \mathrm{~min}$ for $\mathrm{SO}_{2}$ and $3.07 \mathrm{ppmv}$ and $9 \mathrm{~min}$ for $\mathrm{HCl}$ at $973 \mathrm{~K}$, (3) $7.72 \mathrm{ppmv}$ and $10 \mathrm{~min}$ for $\mathrm{SO}_{2}$ and 2.61 ppmv and $5 \mathrm{~min}$ for $\mathrm{HCl}$ at $1073 \mathrm{~K}$, and (4) $10.94 \mathrm{ppmv}$ and 5 min for $\mathrm{SO}_{2}$ and $12.7 \mathrm{ppmv}$ and $1 \mathrm{~min}$ for $\mathrm{HCl}$ at $1173 \mathrm{~K}$, respectively, with a 1 min sampling interval. The variation of concentrations of pollutants (other than $\mathrm{CO}_{2}$ ) with the time indicated that the reaction times required are all less than 10 min for plasma torch pyrolysis. From the points of view of suppression of pollutants emitted and reduction of the power consumption, the reaction temperature may be controlled at $973 \mathrm{~K}$.

Properties of Accumulated Gaseous Products. The accumulated mass and volume fractions of the gaseous products $\left(\mathrm{CO}, \mathrm{H}_{2}, \mathrm{NO}_{x}, \mathrm{CO}_{2}, \mathrm{SO}_{2}\right.$, and $\mathrm{HCl}$ ) (excluding the carrier gas of $\mathrm{N}_{2}$ ) relative to the total mass and volume of gaseous products in wt $\%$ and vol \% for four reaction temperatures are shown in Figure 6. Figure 7 shows the accumulated syngas yields versus $T$ for the pyrolysis of sunflower-oil cake using the plasma torch. 

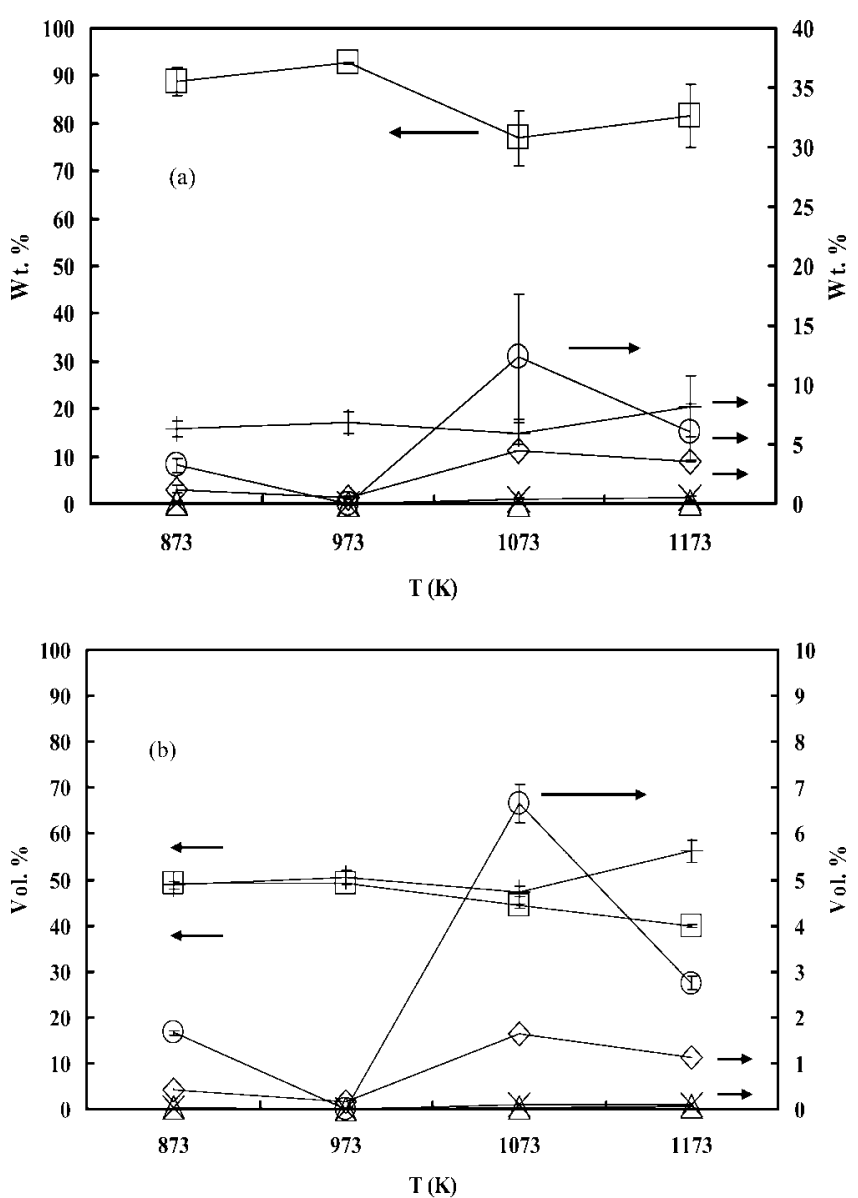

Figure 6. Accumulated percentages of gaseous products (excluding the carrier gas of $\mathrm{N}_{2}$ ) from the pyrolysis of sunflower-oil cake using the plasma torch at various temperatures. $(\square) \mathrm{CO},(+) \mathrm{H}_{2},(\bigcirc) \mathrm{NO}_{x}$, $(\diamond) \mathrm{CO}_{2},(\times) \mathrm{SO}_{2}$, and $(\triangle) \mathrm{HCl}$. (a) Weight percent and (b) volume percent.

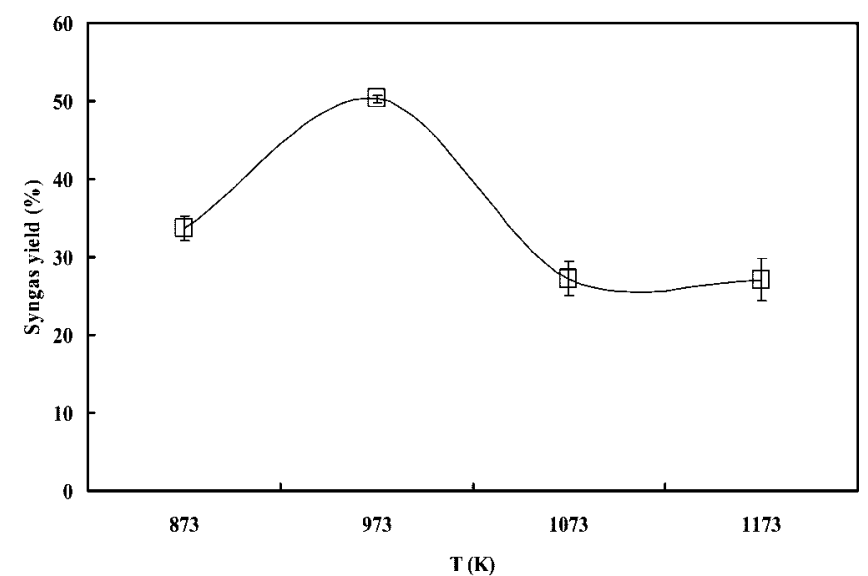

Figure 7. Syngas yields versus $T$ for the pyrolysis of sunflower-oil cake using the plasma torch (relative to the primary input material).

The composition of effluent gases at the outlet of the reactor can be seen in Table 4. From Figure 6 and Table 4, the maximum accumulated mass fractions (or volume fractions) and the corresponding occurring temperatures are $93.17 \mathrm{wt} \%$ (51.17 vol \%) for $\mathrm{CO}$ at $973 \mathrm{~K}$ and $8.21 \mathrm{wt} \%(56.13 \mathrm{vol} \%)$ for $\mathrm{H}_{2}$ at $1173 \mathrm{~K}$, respectively. From Figure 7, the maximum accumulated syngas $\left(\mathrm{CO}\right.$ plus $\left.\mathrm{H}_{2}\right)$ mass fraction (relative to the primary input material) and the corresponding occurring temperature are 50.3 wt $\%$ and $973 \mathrm{~K}$. The yield of $\mathrm{H}_{2}$ increases with the increase of the temperature. At $873 \mathrm{~K}, \mathrm{CO}$ and $\mathrm{H}_{2}$ have near equal volume fractions of 49.1 and $48.72 \mathrm{vol} \%$, respectively. Table 5 shows the contrasts of different materials for pyrolysis or gasification via various reactors and plasma technologies from references and this study. In comparison to references (Table 5), the volume fractions of $\mathrm{CO}$ and $\mathrm{H}_{2}$ using pyrolysis via plasma technology in this study have near volume fractions of $\mathrm{CO}$ and $\mathrm{H}_{2}$ using gasification via traditional reactors or plasma technologies. The yields of $\mathrm{H}_{2}$ in this study have more mass or volume fractions. The reason may be due to the $14.5 \mathrm{wt} \%$ oil content (Table 1) in the sunflower-oil cake. The content of $\mathrm{H}$ of sunflower oil is $13.25 \mathrm{wt} \% .^{29}$ The oil content will increase the yield of $\mathrm{H}_{2}$ in pyrolysis via plasma technology. Figure 8 shows the pollutants yields versus $T$ for the pyrolysis of sunflower-oil cake using the plasma torch. From Figure 6 and Table 4, it is noted that the accumulated mass (or volume) fraction of $\mathrm{NO}_{x}$ suddenly rises to a maximum value of $12.38 \mathrm{wt} \%$ (or $6.65 \mathrm{vol} \%$ ) as the temperature increases to $1073 \mathrm{~K}$. This implies again that the elevated reaction temperature causes a significant emission of $\mathrm{NO}_{x}$. From Figure 8, the minimum accumulated pollutant $\left(\mathrm{CO}_{2}\right.$, $\mathrm{NO}_{x}, \mathrm{SO}_{2}$, and $\mathrm{HCl}$ ) mass fractions (relative to the primary input material) and the corresponding temperature are $0.3 \mathrm{wt} \%$ and 973 K. Figure 9 and Table 3 show the $90 \%$ reaction time per mass $\left(t_{90} / m_{\mathrm{s}}\right)$ from the pyrolysis of sunflower-oil cake using the plasma torch at various temperatures. The lowest value of $t_{90} /$ $m_{\mathrm{s}}$ is at $973 \mathrm{~K}$; therefore, the reaction rate at $973 \mathrm{~K}$ has the highest value. The optimum reaction condition should be controlled at $973 \mathrm{~K}$ or $14-22 \mathrm{~kW}$ of power. Hrabovsky et al. ${ }^{30}$ used an experimental reactor equipped with the hybrid gas-water stabilized torch with an arc power up to $160 \mathrm{~kW}$ to examine the gasification and pyrolysis of wood. Dependent upon the operation conditions, the main components of produced syngas were $\mathrm{H}_{2}\left(28-46\right.$ vol \%), $\mathrm{CO}$ (44-68 vol \%), $\mathrm{CO}_{2}$ (2-8 vol \%), and $\mathrm{Ar}(0.2-8$ vol \%). From this reference and others (Table $5)$, no complex hydrocarbons and tar were detected in plasma technologies. Therefore, the analyses of hydrocarbons and tar were not performed in this study.

Characteristics of the Plasma Torch Applications in Biomass Use. In this study, the feedstock of sunflower-oil cake was treated by a plasma torch in a reactor chamber, whereby organic components were converted into a syngas of high caloric value and inorganic components were converted into nonleachable vitrified lava. The weight percentages of lava are between 16 and 9 wt \% for the reaction temperatures of 873-1173 K, respectively. Thermal plasma can offer high temperatures for the pyrolysis of solid fuel and treatment of wastes. Advantages of thermal plasma-based technologies over conventional incineration include higher temperatures, independence of additional fuel, and shorter residence times. ${ }^{31}$ In comparison to the conventional thermal pyrolysis of sunflower-oil cake, the residues of char are between 24.2 and $42.32 \mathrm{wt} \%$ for the temperatures from 973 to $673 \mathrm{~K}$, respectively. ${ }^{32}$ A plasma-based remediation system is one of the technologies that can prevent or reduce undesired pollutants in the byproducts and end product (such as syngas or other gases). The problem to be solved is 2-fold: recuperate clean energy from waste and renewables without or with less pollution meeting with the requirement at affordable costs. Such a technique fulfills the objectives of sustainable development. ${ }^{1}$ Tar content in the produced gas from the pyrolysis or gasification of biomass always plays an important role because high tar content disables some potentialities of the

(30) Hrabovsky, M.; Konrad, M.; Kopecky, V.; Hlina, M.; Kavka, T.; Chumak, O.; van Oost, G.; Beeckman, E.; Defoore, B. High Temp. Mater. Processes 2006, 10, 557-570.

(31) Kezelis, R.; Mecius, V.; Valinciute, V.; Valincius, V. J. High Temp. Mater. Process 2004, 8, 273-282.

(32) Gercel, H. F. Biomass Bioenergy 2002, 23, 307-314. 
Table 4. Composition of Effluent Gases at the Outlet of the Plasma Torch Reactor (Excluding the Carrier Gas of $\mathbf{N}_{2}$ )

\begin{tabular}{|c|c|c|c|c|c|c|}
\hline target temperature $(\mathrm{K})$ & $\mathrm{CO}$ & $\mathrm{H}_{2}$ & $\mathrm{CO}_{2}$ & $\mathrm{NO}_{x}$ & $\mathrm{SO}_{2}$ & $\mathrm{HCl}$ \\
\hline 873 & $\begin{array}{l}88.95^{a} \\
(2.95)\end{array}$ & $\begin{array}{l}6.30 \\
(0.70)\end{array}$ & $\begin{array}{l}1.23 \\
(0.37)\end{array}$ & $\begin{array}{l}3.23 \\
(0.57)\end{array}$ & $\begin{array}{l}0.18 \\
(0.05)\end{array}$ & $\begin{array}{l}0.10 \\
(0.03)\end{array}$ \\
\hline 873 & $\begin{array}{l}49.10^{b} \\
(0.27)^{c}\end{array}$ & $\begin{array}{l}48.72 \\
(0.89)\end{array}$ & $\begin{array}{l}0.43 \\
(0.02)\end{array}$ & $\begin{array}{l}1.67 \\
(0.05)\end{array}$ & $\begin{array}{l}0.04 \\
(0.00)\end{array}$ & $\begin{array}{l}0.04 \\
(0.00)\end{array}$ \\
\hline 973 & $\begin{array}{l}93.17 \\
(0.11)\end{array}$ & $\begin{array}{l}6.33 \\
(0.73)\end{array}$ & $\begin{array}{l}0.49 \\
(0.13)\end{array}$ & $\begin{array}{l}0.01 \\
(0.00)\end{array}$ & $\begin{array}{l}0.06 \\
(0.02)\end{array}$ & $\begin{array}{l}0.01 \\
(0.00)\end{array}$ \\
\hline 973 & $\begin{array}{l}51.17 \\
(0.01)\end{array}$ & $\begin{array}{l}48.65 \\
(1.27)\end{array}$ & $\begin{array}{l}0.17 \\
(0.01)\end{array}$ & $\begin{array}{l}0.00 \\
(0.00)\end{array}$ & $\begin{array}{l}0.01 \\
(0.00)\end{array}$ & $\begin{array}{l}0.00 \\
(0.00)\end{array}$ \\
\hline 1073 & $\begin{array}{l}44.24 \\
(0.5)\end{array}$ & $\begin{array}{l}47.35 \\
(1.13)\end{array}$ & $\begin{array}{l}1.65 \\
(0.00)\end{array}$ & $\begin{array}{l}6.65 \\
(0.42)\end{array}$ & $\begin{array}{l}0.09 \\
(0.02)\end{array}$ & $\begin{array}{l}0.02 \\
(0.01)\end{array}$ \\
\hline 1173 & $\begin{array}{l}81.51 \\
(6.53)\end{array}$ & $\begin{array}{l}8.21 \\
(2.52)\end{array}$ & $\begin{array}{l}3.57 \\
(0.07)\end{array}$ & $\begin{array}{l}6.05 \\
(2.41)\end{array}$ & $\begin{array}{l}0.47 \\
(0.18)\end{array}$ & $\begin{array}{l}0.18 \\
(0.04)\end{array}$ \\
\hline 1173 & $\begin{array}{l}39.82 \\
(0.44)\end{array}$ & $\begin{array}{l}56.13 \\
(2.36)\end{array}$ & $\begin{array}{l}1.11 \\
(0.00)\end{array}$ & $\begin{array}{l}2.76 \\
(0.15)\end{array}$ & $\begin{array}{l}0.10 \\
(0.02)\end{array}$ & $\begin{array}{l}0.07 \\
(0.03)\end{array}$ \\
\hline
\end{tabular}

${ }^{a}$ In wt $\% .{ }^{b}$ In vol $\% .{ }^{c}$ Numbers in parentheses are standard deviations $\left(\sigma_{n}\right)$.

Table 5. Contrasts of Different Materials for Pyrolysis or Gasification via Various Reactors and Plasma Technologies from the References and This Study (Excluding of $\mathrm{N}_{2}$ and $\mathrm{H}_{2} \mathrm{O}$ )

\begin{tabular}{|c|c|c|c|c|c|c|c|c|c|c|}
\hline \multirow{2}{*}{ author } & \multirow[b]{2}{*}{ apparatus } & \multirow[b]{2}{*}{ target temperature $(\mathrm{K})$} & \multirow[b]{2}{*}{ process } & \multirow[b]{2}{*}{ sample } & \multicolumn{6}{|c|}{ vol \% } \\
\hline & & & & & $\mathrm{CO}$ & $\mathrm{H}_{2}$ & $\mathrm{CH}_{4}$ & $\mathrm{C}_{2} \mathrm{H}_{6}$ & $\mathrm{C}_{2} \mathrm{H}_{4}$ & $\mathrm{CO}_{2}$ \\
\hline Demirbas $^{23}$ & direct-heated process & $295-973$ & gasification & elm & 17.1 & 44.3 & 7.9 & & & 27.5 \\
\hline \multirow[t]{4}{*}{ Zanzi et al. ${ }^{24}$} & free-fall reactor & 1273 & pyrolysis & straw & 46.2 & 43.9 & 4.8 & & & 5 \\
\hline & & & & straw pellets & 48.4 & 38.8 & 8 & & 0.1 & 4.7 \\
\hline & & & & olive waste & 47.4 & 21.1 & 18.3 & 0.2 & 0.5 & 12.3 \\
\hline & & & & wood: birch & 45.7 & 34 & 11.7 & & 0.5 & 7.5 \\
\hline \multirow[t]{2}{*}{$\mathrm{Le}^{\prime} \mathrm{de}^{25}$} & RAPB & & pyrolysis & wood & 52 & 30 & & & & 9 \\
\hline & & & & kraft & 38 & 52 & & & & 9 \\
\hline \multirow[t]{6}{*}{ Tomasi et al. ${ }^{26}$} & fluidized-bed reactor & 1068 & gasification & bagasse & 44.73 & 51.08 & 1.18 & & & 2.97 \\
\hline & & 1071 & & pine sawdust & 44.30 & 51.71 & 1.18 & & & 2.77 \\
\hline & & 1054 & & poplar sawdust & 43.63 & 51.35 & 1.34 & & & 3.63 \\
\hline & & 1047 & & cotton stalks & 41.86 & 51.94 & 1.58 & & & 4.54 \\
\hline & & 1103 & & almond shells & 46.64 & 50.70 & 0.85 & & & 1.78 \\
\hline & & 1079 & & olive wastes & 43.86 & 52.62 & 1.12 & & & 2.36 \\
\hline \multirow[t]{3}{*}{ Zhao et al. ${ }^{11}$} & plasma torch & & pyrolysis & wood A & 31.91 & 58.64 & 2.81 & & & 1.12 \\
\hline & & & & wood B & 33.18 & 57.82 & 3.00 & & & 1.06 \\
\hline & & & & rice husk & 13.38 & 83.45 & 1.13 & & & 0.68 \\
\hline Tang et al. ${ }^{27}$ & plasma torch & 1073 & pyrolysis & polypropylene & 4.48 & 80.85 & 8.52 & 0.38 & 5.77 & \\
\hline Rutberg et al. ${ }^{28}$ & plasma torch & 1473 & gasification & wood & 57.19 & 42.81 & & & & \\
\hline \multirow[t]{3}{*}{ Tendler et al. ${ }^{1}$} & plasma torch & 2223 & gasification & wood & 52.86 & 41.25 & & & & 5.89 \\
\hline & & 2273 & & RDF & 48.25 & 46.14 & & & & 5.61 \\
\hline & & 2073 & & car tires & 40.13 & 51.17 & & & & 8.70 \\
\hline \multirow[t]{2}{*}{ van Oost et al. ${ }^{4}$} & $\mathrm{Ar} / \mathrm{H}_{2} \mathrm{O}$ plasma torch & 1973 & gasification & run $1-\mathrm{A}$ (wood chip) & 48.32 & 50.59 & & & & 1.08 \\
\hline & & & & run $2-\mathrm{A}$ (wood chip) & 50.05 & 47.89 & & & & 2.05 \\
\hline \multirow[t]{4}{*}{ this study } & plasma torch & 873 & pyrolysis & sunflower-oil cake & 49.10 & 48.72 & & & & 1.23 \\
\hline & & 973 & & & 51.17 & 48.65 & & & & 0.17 \\
\hline & & 1073 & & & 44.24 & 47.35 & & & & 1.65 \\
\hline & & 1173 & & & 39.82 & 56.13 & & & & 1.11 \\
\hline
\end{tabular}

further treatment of the gas produced. Plasma torch technologies for the pyrolysis or gasification of biomass not only yield high concentrations of syngas but also result in low concentrations of tar in a gas phase, mostly below $10 \mathrm{mg} \mathrm{N} \mathrm{m}^{-3}$. $^{3}$ Therefore, plasma torch technology is characterized with its elevated energy density reducing the residual ash and converting it into nonleachable vitrified lava. Thermal plasmas torch, which is a heating source with very high temperatures and steep temperature gradients, offers an attractive and chemically nonspecific route for the synthesis of syngas. Different from the radiofrequency $(\mathrm{RF})$ or microwave plasma via high-frequency discharges, the thermal plasma torch primarily uses a highintensity torch for the synthesis of syngas. ${ }^{12}$ The elevated heating speed allows the regime to reach conditions quickly, and the energy flux is also high. Moreover, the elevated temperature allows for the treatment or processing of target materials and the formation of needed products taking place simultaneously, reducing the need for the post-treatment of waste stream and residues. However, there is a vitally important concern of the use of electric energy, because it can substantially raise the operating cost of the use of the plasma torch. To overcome parts of this problem, the need of electric energy for the plasma torch may be supplied partly from the power generated via the use of the product of syngas. Tendler et al. ${ }^{1}$ analyzed the energy efficiency of the gasification and pyrolysis of wood, residuederived fuel (RDF), and car tires via the plasma torch. The energy productions of syngas for the steam thermodynamic cycle (about 35\% efficiency) and combined cycle (about 52\% efficiency) were 5.35 and $7.96 \mathrm{MJ} \mathrm{kg}^{-1}$ from wood, 5.06 and 7.52 $\mathrm{MJ} \mathrm{kg}^{-1}$ from RDF, and 10.37 and $15.27 \mathrm{MJ} \mathrm{kg}^{-1}$ from car tires, respectively. In comparison to the energy consumptions of processing wood, RDF, and car tires for plasma torch gasification of $3.6,3.82$, and $6.66 \mathrm{MJ} \mathrm{kg}^{-1}$, respectively, the energy stored in syngas is higher than the energy consumption from the operation of the plasma torch. In another new thermal plasma process development, Kezelis et al. ${ }^{31}$ used plasma generated in alternate-current (AC) air plasma and direct-current (DC) steam plasma torches for the production of syngas from 


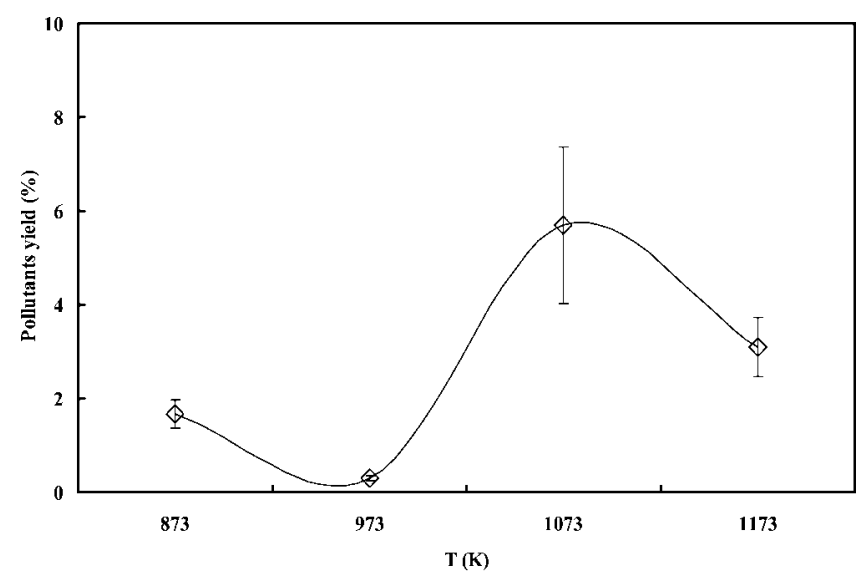

Figure 8. Pollutant yields versus $T$ for the pyrolysis of sunflower-oil cake using the plasma torch. Pollutants $=\mathrm{CO}_{2}, \mathrm{NO}_{x}, \mathrm{SO}_{2}$, and $\mathrm{HCl}$ (relative to the primary input material).

wood. The mean enthalpy of plasma, both for the AC and DC torches, given by the ratio of net arc power/gas flow rate, is usually not higher than $10 \mathrm{MJ} \mathrm{kg}^{-1}$. On the other hand, the investment costs of plants with a plasma torch are typically $30-50 \%$ lower than those of incinerators with the same capacity. ${ }^{14}$ Another effect of the operational cost for the plasma torch application is the cost of feedstock. Therefore, the best choice of feedstock is waste from biomass or waste organic materials. A consumption of agricultural residues for energy production would also reduce the environmental damage. For instance, $\mathrm{CO}_{2}$ emission in agricultural residues is $94 \mathrm{~g} \mathrm{MJ}^{-1}$, while it is $140 \mathrm{~g} \mathrm{MJ}^{-1}$ in lignite. ${ }^{33}$ In general, the use of biomass substituting fossil fuels for electricity and heat production is less costly and more efficient for resource use than replacing gasoline or diesel for transportation.

\section{Conclusions}

This study investigated the results of a new research and development program for plasma torch technology on the applications for biomass energy use, which has been started and conducted at the INER-AEC of Taiwan, together with the academic partners of NTU and NIU. The present work performed the biomass treatment using a pilot-scale thermal

(33) Acaroglu, M.; Aksoy, A. S.; Ogut, H. Energy Sources 1999, 21, $339-345$.

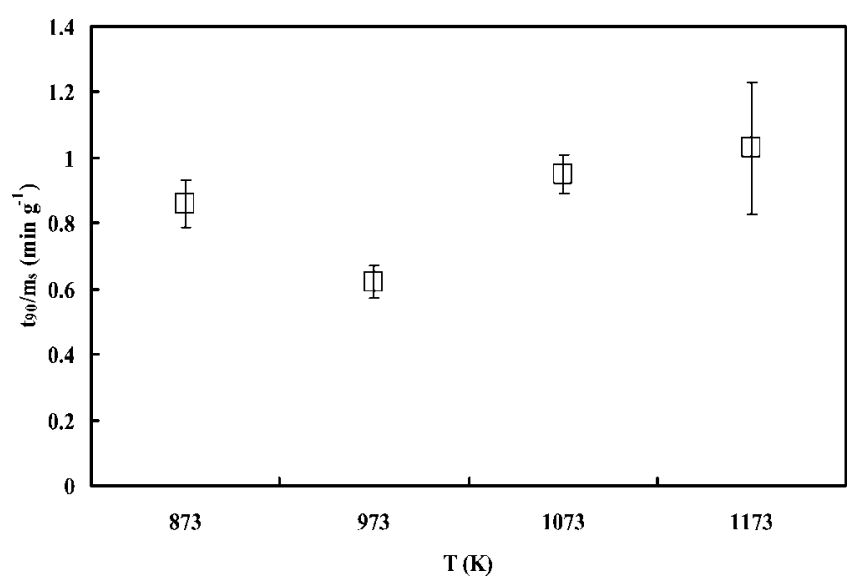

Figure 9. $90 \%$ reaction time per mass $\left(t_{90} / m_{\mathrm{s}}\right)$ from the pyrolysis of sunflower-oil cake using the plasma torch at various temperatures.

plasma torch as the heat source and sunflower-oil cake as feedstock. For the production of $\mathrm{CO}$ and $\mathrm{H}_{2}$ (syngas), the maximum accumulated mass fractions (or volume fractions) and the corresponding occurring temperatures are $93.17 \mathrm{wt} \%(51.17$ vol \%) for $\mathrm{CO}$ at $973 \mathrm{~K}$ and $8.21 \mathrm{wt} \%(56.13 \mathrm{vol} \%)$ for $\mathrm{H}_{2}$ at $1273 \mathrm{~K}$, respectively. At $873 \mathrm{~K}, \mathrm{CO}$ and $\mathrm{H}_{2}$ have near equal volume fractions of 49.1 and $48.72 \mathrm{vol} \%$, respectively. At 973 $\mathrm{K}$, the reaction rate and syngas yield have the highest values and the yields of the pollutant have the lowest values. Therefore, the optimum reaction condition should be controlled at $973 \mathrm{~K}$ or $14-22 \mathrm{~kW}$ of power. The maximum instantaneous concentrations of $\mathrm{CO}$ and $\mathrm{H}_{2}$ appear at a very short time of $1-5 \mathrm{~min}$. The pyrolysis of the sunflower-oil cake via the plasma torch producing syngas can be accomplished in a short time of about 15 min. The inorganic components were converted into nonleachable vitrified lava, which is nonhazardous. Thus, the results of this study provide useful information for converting sunfloweroil cake to syngas via the proposed plasma torch pyrolysis technique.

Acknowledgment. We express our sincere thanks to the Institute of Nuclear Energy Research, Atomic Energy Council (INER-AEC) of Taiwan for the financial support, under contract number 952001INER012, and Mr. Lin-Chiu Tsai, Mr. Der-Heui Shieh, and Mr. Shyh-Chang Hwang of INER-AEC for their technical support.

EF700301V 